4. Austen, J. Northanger Abbey. URL: https://www.gutenberg.org/files/ 121/121-h/121-h.htm

5. Cambridge Advanced Learner's Dictionary. URL: https://dictionary.cambridge.org/dictionary/english/

DOI https://doi.org/10.30525/978-9934-26-039-1-76

\title{
ПОЕТИЧНІ ПЕРЕКЛАДИ В. БРЮСОВА (НА МАТЕРІАЛІ АНГЛІЙСЬКОЇ ПОЕЗІї)
}

\author{
Палій К. В. \\ кандидат філологічних наук, \\ старший викладач кафедри германської філологї та перекладу \\ Національного університету «Полтавська політехніка \\ імені Юрія Кондратюка» \\ Воробйова О. С. \\ кандидат філологічних наук, \\ доиент кафедри германської філології та перекладу \\ Національного університету «Полтавська політехніка \\ імені Юрія Кондратюка» \\ Астахова C. A. \\ викладач кафедри германської філологї̈ та перекладу \\ Національного університету «Полтавська політехніка \\ імені Юрія Кондратюка» \\ м. Полтава, Україна
}

Валерій Якович Брюсов не лише відомий поет, прозаїк, літературознавець, теоретик вірша, критик, історик, а й сміливий перекладачноватор, який збагатив і тематику, i стилістику, і метрику сучасної поезії. В. Брюсов багато займався поетичними перекладами, він відкрив читачеві творчість Еміля Верхарна, був першим перекладачем віршів Поля Верлена, всесвітньо відомі переклади В. Брюсова творів Е. По, Ромена Роллана, Моріса Метерлінка, Віктора Гюго, Ж. Расіна, Мольєра, Дж. Байрона, Оскара Уайльда, Й. Гете, Вергілія та ін.

Слід зазначити, що не все в його перекладах було рівноцінно, існувало дуже багато протиріч: він намагався дійти до меж можливого в 
суперечливих крайнощах перекладацького мистецтва - i у вільному, і в дослівному перекладі.

Вивчаючи перекладацьку діяльність В. Брюсова, необхідно зазначити, що він звертався лише до тих поетів, які дійсно захоплювали його, в яких він відчував духовну та ідейну спорідненість 3 його власними поетичними прагненнями. Звернення до перекладів іноді стимулювалося полемікою 3 колегами, зокрема, з К. Д. Бальмонт та А. А. Курсинськмм. Особливу увагу В. Брюсова привертають Дж. Байрон, В. Шекспір, П. Шеллі і Т. Мур, О Уайльд.

Перекладач ставив перед собою завдання «розхитати» стару перекладацьку школу, в тому числі теоретичні погляди П. І. Вейнберга. В. Брюсов віддавав перевагу максимально ретельному відтворенню словесної і ритміко-синтаксичної структури твору, вказував на неприпустимість руйнування строфічного ладу, зовнішньої поетичної форми.

У перекладах В. Брюсова виділяються, переклади історично синхронні (О. Уайльд, О. Добсон) і діахронні (В. Шекспір), коли виникала необхідність передачі не тільки національно-художньої своєрідності, але й цінностей минулої епохи, оскільки ставилося питання про архаїзацію або модернізацію перекладів [2, с. 373].

Якщо слідувати хронологічному принципу появи перекладів 3 англійської поезії, то одним із перших поетів, який зацікавив В. Брюсова, як і багатьох інших перекладачів, став Т. Мур. Для поетів-символістів Т. Мур виявився привабливим як автор ліричних віршів, що відрізняються вишуканістю в поетиці, елегійністю і мелодійністю.

У своєму перекладі вірша Т. Мура «Joys of youth, how fleeting!» 3 циклу «Мелодії різних народів» В. Брюсов дуже незначно відходить від оригіналу, акцентуючи і посилюючи елегійність другої строфи вірша $[5$, с. $39-40]$.

Переклади чотирьох віршів Р. Л. Стівенсона із збірника «Дитячий квітник віршів» («A Child's Garden of Verses «) розкривають $з$ маловідомої сторони В. Брюсова. Поет цурався дітей і по-справжньому прив'язався тільки до свого прийомного сина Колі. Вірші Р. Л. Стівенсона допомогли В. Брюсову знайти вірний шлях у літературі для дітей шлях лірики і автобіографічності, стали своєрідним alter ego перекладача, що відобразилося в його збірці «Сем цветов радуги» в розділі віршів для дітей. Стислість, простота, характерні для англійського поета, знайшли своє відображення в перекладах В. Брюсова [1, с. 40; 42].

Переклади Дж. Байрона численні, але одним із найвизначнішим $\epsilon$ переклад ліричного твору: «Ода к Наполеону» («Ode to Napoleon Buonaparte»). У поезії Дж. Байрона образ Наполеона займає особливе місце, ставлення поета до нього двояке. Роль Наполеона в європейській 
історії, його героїзація і розвінчання отримують у Дж. Байрона яскраві емоційні оцінки. У англійського поета немає «розпливчастих» слововживань, вибір слів, відтінків, значень завжди чіткий. Такими є деякі визначення «володаря» світу: «the Arbiter of others' fate», «vile as vulgar clay», «by man accurst», «vain forward child of Empire»,»the man of thousand thrones»,»a nameless thing», «ill-minded man»,»the Victor overthrown». Не всі важливі епітети 3 тексту Дж. Байрона присутні в перекладі, не всі зміни В. Брюсова органічні, часом вони призводять до суттєвих смисловим розбіжностей (наприклад, в XIII строфі: proud Austria's mournful flower - «цветок австрийский гибкий...»; «late repentance» - «ропот поздний»). Проте В. Брюсов не випадково наполягав в одному із листів до С. Венгерова з приводу своїх перекладів Дж. Байрона на допустимість збільшень і замін: «Перевод слишком часто вынужден обесцвечивать подлинник, и «красочные отсебятины» переводчика несколько вознаграждают читателя; необходимо только, чтобы они были в духе и стиле оригинала» [2, с. 374]. В. Брюсов прагнув зберегти звукову, граматичну, ритмико-інтонаційну системи. Однак першим і головним завданням його при перекладі Оди стало те, щоб вона «представляла и по-русски самостоятельный интерес, чтобы ее можно было читать, забыв, что это перевод» [2, с. 376]. Саме тому перекладач сміливо жертвує близькістю до оригіналу, іноді дозволяє собі переставляти вірші місцями, дещо опускає або додає, але «все перемены, прибавления, опущения сделаны не по произволу, а обдуманно» [2, с. 377]. Щоб подолати напругу і протиріччя двох взаємодіючих структур - зміст і особливості оригіналу, з одного боку, і сукупність образних і стилістичних рис мови перекладача, а з іншого боку, - В. Брюсов віддавав перевагу збереженню «правильности языка». Митець вважав, що ціннісні орієнтири байронівської оди при їх адекватному відтворенні мовою перекладу можуть бути витлумачені вибірково i досить локально. XVIII строфа перекладу оди не $\epsilon$ близькою до мови оригіналу, але вона демонструє те «самое серьезное отношение» до справи, яке ставив собі в заслугу В. Брюсов.

Byron

But thou forsooth must be a King

And don the purple vest,

As if that foolish robe could wring

Remembrance from thy breast.

Where is that faded garment? where

The gewgaws thou wert fond to wear,

The star, the string, the crest?

Vain forward child of Empire! say, 
Are all thy playthings snatched away?

Но низкой жаждой самовластья

Твоя душа была полна.

Ты думал: на вершину счастья

Взнесут пустые имена!

Где ж пурпур твой поблекший ныне?

Где мишура твоей гордыни:

Султаны, ленты, ордена?

Ребенок бедный! Жертва славы!

Скажи, где все твои забавы?

Майстер вірша, сміливий новатор ідей та перекладу В. Брюсов в перекладах своїх завжди допитливо шукав такі форми і поєднання слів, щоб швидше за все знайти відгук у читача, «поразить» його увагу, змусити запам'ятати «невольно и навсегда» [3, с. 457-458].

\title{
Література:
}

1. Беджанян К. Г. Подробно о переводах из Стивенсона. Научные труды. Вопросы филологии. Ереван, 2003. Выпуск № 1. С. 40-46.

2. Брюсов В. Я. Мастерство перевода. Сборник статей. М. 1959. C. $373-377$.

3. Брюсов В. Я. Собрание сочинений : в 7 т. М. : Худож. лит., 1973. T. $3.672 \mathrm{c}$.

4. Брюсов В. Я. Собрание сочинений : в 7 т. М. : Худож. лит., 1973. T. 7. $496 \mathrm{c}$.

5. Мур Т. Валерий Брюсов. Литературное наследство. М., 1986. T. 91. C. 39-40.

DOI https://doi.org/10.30525/978-9934-26-039-1-77

\section{ПРОБЛЕМИ ПЕРЕКЛАДУ МЕДИЧНИХ ТЕРМІНІВ}

\author{
Пуш О. М. \\ старший викладач кафедри перекладу та філології \\ ЗВО «Університет Короля Данила» \\ м. Івано-Франківськ, Україна
}

Актуальність дослідження обумовлюється тим, що термінологія, яка обслуговує медицину, є однією з найбагатших термінологічних систем. Вона безперервно поповнюється новими термінами, які потребують 80 